\title{
THE OEUVRE OF PROFESSOR GYULA HAJNÓCZI IN THE PRESENTATION OF THE BUILT ROMAN HERITAGE IN PANNONIA ${ }^{\#}$
}

\author{
TAMÁS MEZÖS \\ CSc, DLA, professor. Department of History of Architecture and Monument Preservation, \\ BME, K II. 82, Müegyetem rkp.3, H-1111 Budapest, Hungary. E-mail: mezos@eptort.bme.hu
}

\begin{abstract}
His activity as a teacher, a researcher and a monument expert architect evenly characterises Gyula Hajnóczi's oeuvre. As a teacher, he held lectures for almost half a century on the subjects of the ancient history of architecture and the universal theory of architecture. He studied and published his findings as an architectural historian, as a researcher of the theory of architecture, as the scholar of Roman architecture, and last but not least, as the discerner of spatial theory of ancient architecture. His life-work in heritage conservation and restoration has not only become well-known in Hungary. Italian, German and Austrian colleagues read his publications, who continuously contacted him to get acquainted with his latest works of art. As a regularly invited lecturer of international conferences, he made particular efforts to promote and to make Hungarian heritage preservation internationally recognised. This paper, due to its restrictive volume, presents the ruin conservation methods from a theoretical point of view, introduces the presentation of protective buildings - being attempts of reduced quality reconstructions; last but not least, it aims to show the theoretically grounded work that supported completing the schematic reconstructions of the buildings.
\end{abstract}

Keywords: Gyula Hajnóczi, Roman archaeological findings, heritage preservation

Gyula Hajnóczi obtained his architect-engineer diploma in 1950, then, in 1958, he received his degree in archaeology. As an assistant lecturer, first, he had shared the lectures on the history of ancient architecture with Erika Malecz, then, after acquiring his diploma in archaeology, he held lectures on the architecture of eastern cultures and the antiquities on his own, already as an associate professor. Under the supervision of his first principal - as he called him, Professor Rados -, he had the opportunity to participate in listed building surveys early on his career, then, also to plan the reconstruction of valuable historical buildings. Together with his colleagues, Károly Ferenc and Elemér Nagy, he surveyed the castles of Nagycenk, Fertöd and Lovasberény, and they also collected fragmented shapes of Hungarian classicist architecture. They developed reconstruction plans to renovate some historical buildings too, in Székesfehérvár, Vác and Esztergom.

\footnotetext{
\# This work was supported by the National Cultural Fund of Hungary (NKA) under Grant Number $101108 / 547$.
} 
He attached particular importance to the survey of buildings throughout his entire career and regarded it as a core component of architect training. As a deputy dean, he developed the program of a historical survey of municipalities for second-year students. The fruit of the two-week intensive work was the documentation of 14 towns in the master plan as well as in street views. In parallel to the development works of the Aquincum Archaeological Park, he organised an international digging camp for undergraduates. Both projects were lifetime experiences for the participants.

\section{THE FIRST TASKS TO PRESENT ROMAN RUINS}

Reviving the ancient monuments of Pannonia was the field where Hajnóczi could express his creativity in its entirety. This study does not present his oeuvre in chronological order. Instead, it is to draw a particular arc of development from the plans reflecting the set of views of Hungarian heritage preservation established early on, between the two wars, to the formation of a unique spatial world of the independent architect in search of ways. The fundamental milestones of the Professor's scientific career preserve the critical mark of this process. As a recently graduated archaeologist, he explains the newly acquired knowledge with the decisive grammatical unit of the architectural language, space. As a real verification, it is sufficient to refer to the uncountable number of schematic reconstruction drawings he created. In his work method, the series of architectural periodisation of archaeological data has provided the basis for the architectural interpretation of the monuments of the given periods. At first, he pictured all this in a single plane, within a plan, then, he built the monument in the $3^{\text {rd }}$ dimension as well. He regarded it essential to verify the authenticity of virtual reconstruction, which meant a plan developed to the point of detail that many times included the joints in the structure too.

The first significant assignment of the Professor was to supervise the archaeological research conducted in the Isis sanctuary, Szombathely, and then to develop its public presentation plans. The accomplishment of the exploratory archaeologist, Tihamér Szentléleky drew the Hungarian public's attention to the excavations. What is more, he had an impact on the international members of the profession too, who were also monitoring the work. The discovery of a few parts of the frieze, namely the lintel element of the trabeated system that bridges the half intercolumniation, was considered a sensational achievement, just as the identification of the cardinal motifs of the abacus ${ }^{1}$. According to the dimensions of the Corinthian column capital, the facade height of the temple could also be identified. At the same time, the fragment of the trabeated system verified the size of the intercolumniation. The supervising archaeologist of the excavation determined the iconographic order of the reliefs of

\footnotetext{
${ }^{1}$ Gyula Hajnóczi's reconstruction drawing was based on the schematic reconstruction of Tihamér Szentléleky. The reconstruction of the frieze that stands today is the work of Géza Alföldy and Zsolt Mráv.
} 

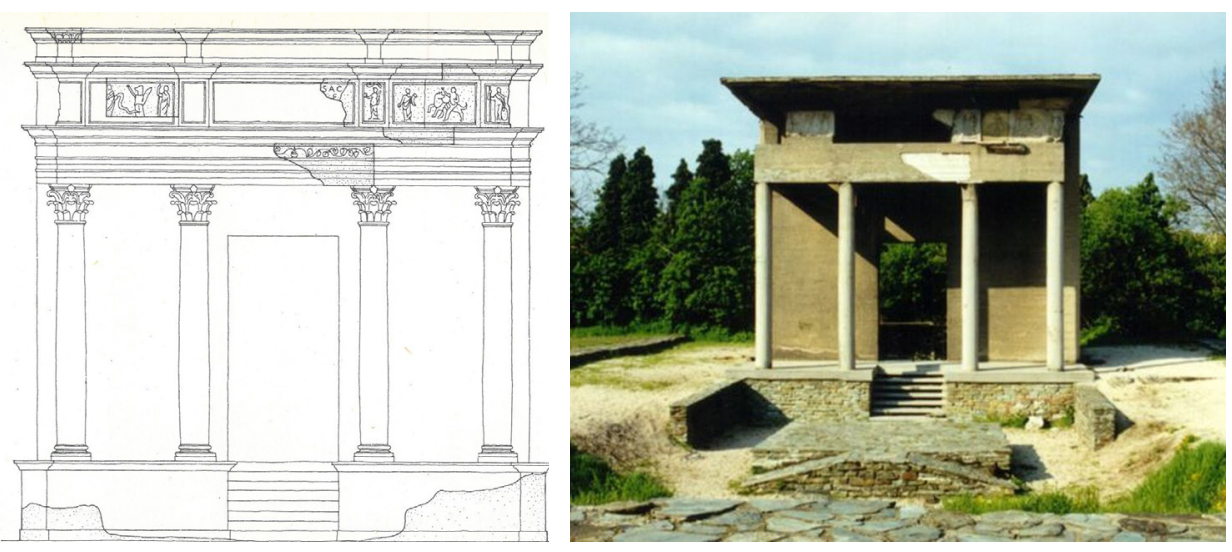

Figure 1. The architectural rendering of the frieze of the Iseum. (Drawing of Gyula Hajnóczi)

Figure 2. Gyula Hajnóczi’s quasi anastylosis Iseum. (Photo: Gyula Hajnóczi)

the frieze (Fig. 1). However, the frontal width formed as a result was less than it should have been according to the foundation wall almost entirely unearthed. Although the possibility of reconstruction did occur to Hajnóczi, due to this new situation and to the reconstruction possibilities of the reliefs based on the archaeological findings he withdrew the idea; after all, he had no other choice but to follow the Hungarian heritage preservation principles, and practically he performed an anastylosis in the public presentation plans and implementation. The poster made in 1963, visualising the presentation of the heritage (Fig. 2), was part of the official program of the Venice congress. As Dezső Dercsényi and Miklós Horler revealed it in their report ${ }^{2}$, the participants celebrated the first implementation of the newly adopted Charter in the Iseum. In their written account, the Hungarian participants attributed a broad level of satisfaction to "their most important assumption regarding the domestic practice 'that in fact, Hungarian heritage conservation and restoration efforts are equivalent to them ${ }^{3}$ [i.e. to that of Athens, the Italian, and to the most recent Venice charter], thus, basically, to the views of the 1930s". The Hungarian society of architects also offered their congratulation to the finished piece of art. It was the presentation of the Iseum that made the Professor a renowned expert in Roman architecture. The fact that Hajnóczi could become virtually the only designer of reconstructions carried out in the period, thanks to the renaissance of Roman archaeology, was naturally the result of these evaluations. However, the Professor had maintained his doubts in connection with schematic reconstruction until the end of

\footnotetext{
${ }^{2}$ Dercsényi, Dezső - Horler, Miklós: Beszámoló az 1964. évi velencei II. Nemzetközi Mủemlékvédelmi Kongresszusról [Report on the $2^{\text {nd }}$ International Congress of Architects and Technicians of Historic Monuments in Venice]. Müemlékvédelem [Heritage Preservation] 8 (1964) 4. 193-216. 207. This congress was the venue where the document which became widely known as the Venice Charter was adopted.

${ }^{3}$ Dercsényi - Horler op. cit. 196.
} 
his life. Once he was in Szombathely, looking at the heritage that was in a deplorable state, already at the beginning of the 90 s he gave the resigned assumption that "even from a perspective of 30 years, the public still rejects the solution that satisfies listed building principles".

It happened slightly earlier that Hajnóczi was invited to participate in the planning process of the development plan concept ${ }^{4}$ managed by the Budapest Urban Development Design Company (BUVÁTI). It was due to the joint work program that brought him into contact with Klára Póczy, archaeologist, he had first met back in their university years in Kolozsvár, in the academic year of 1940/41. After adopting the development plans, the municipality of Budapest initiated the implementation of the verification excavations at the ruins of Aquincum and, based on the new results, the public presentation plan process of the monuments as well. Póczy managed the archaeological research ${ }^{5}$, while Hajnóczi was assigned for architecture activities, including taking over the role of operating as an excavation architect.

\section{UTILISING THE THEORETIC TOOLS IN THE PRESENTATION OF RUINS}

After the verification excavations, managing the periods appropriate for presentation was the major problem. Analysing the condition of the remains led to the decision. The state of the ruins originating from the earliest, $1^{\text {st }}$ century period and the reconstruction of the plan of the buildings did not allow a coherent presentation. Thus, after its thorough documentation, this architectural period had been sacrificed for the benefit of adequately presenting the unity of the ruins of buildings built later. Although they were of stone, even the remains originating from the $2^{\text {nd }}$ century could only sporadically preserve the functional unit of the building. When there was a possibility to present coherent spatial elements, the ruins were presented as "floor motivation" at the height of the walking surface. The remains of the antique town's golden age, the $3^{\text {rd }}$ century, have been preserved in a relatively good condition, appropriate for presenting the spatial structure. Thus, researchers accepted the presentation of this period. In terms of foreign examples, in general, internal space could not be distinguished from other spatial types. It was in Aquincum that the characteristic colour code was used for the first time; according to which the internal spaces were covered by red slag - referring to the Roman terrazzo floor. The semi-external areas, like the porticus, were covered by white crushed stone. The open-air space,

\footnotetext{
${ }^{4}$ The plans that were being worked out in 1962 are credited to a young architect, Ágnes Vladár, from BUVÁTI. Dr. Klára Póczy was the archaeologist consultant, while dr. Gyula Hajnóczi was the architect consultant, who had just recently obtained his doctorate in arts and humanities.

${ }^{5}$ In the Hungarian terminology, the excavation architect (Grabungsarchitekt) is not a widely known and practised profession. However, an architect who is involved in the excavation process - due to his/her qualifications - might be experienced in observing or explaining a lot of details that would skip the archaeologist's attention.
} 
either in case it was a road of the town or the yard of a house, was sewed down to grass. The passages and heating corridors uncovered during the excavations had gotten yellow pea gravel spread.

The third innovation introduced at the presentation was the application of the didactic band. An approximately $10 \mathrm{~cm}$ thick mortar band coloured by iron oxide was layered on the crown of the wall. The pieces of masonry above the mark were finished according to the architect's instructions. It was when he was working at the Gorsium in the 60s that Hajnóczi attempted to determine the height of the masonry ballast with one single plane. The ruins of the building called Palatium, as a result, were seen as a lifeless pile of masonry. Thus, Hajnóczi did not continue this practice later on. When determining the height of the protective masonry walls, he took into account, on the one hand, the size of the crown of the wall survived from the remains, and on the other, the fact that rooms bricked up higher always intended to raise the visitors' attention. The identification of individual buildings of the town referred to as the onetime religious centre of Pannonia, still needs further clarification. The excavations of constructions related to the age of Traianus Hadrianus ( $2^{\text {nd }}$ century) uncovered remains that had their origins in the middle and western part of the assumed religious centre of the province. At the same time, the ruins excavated west of the decumanus had their origins in the age of Diocletianus ( $3^{\text {rd }}$ century). The joint presentation of these is still an unsolved problem of providing experience to the public.

The self-evident aim of the architect is to render spaces perceptible for the audience. Hajnóczi attempted to demonstrate the mass of the little weighing house, rotunda (Fig. 3), located in the meat market next to Cardo. Lacking data, he elevated

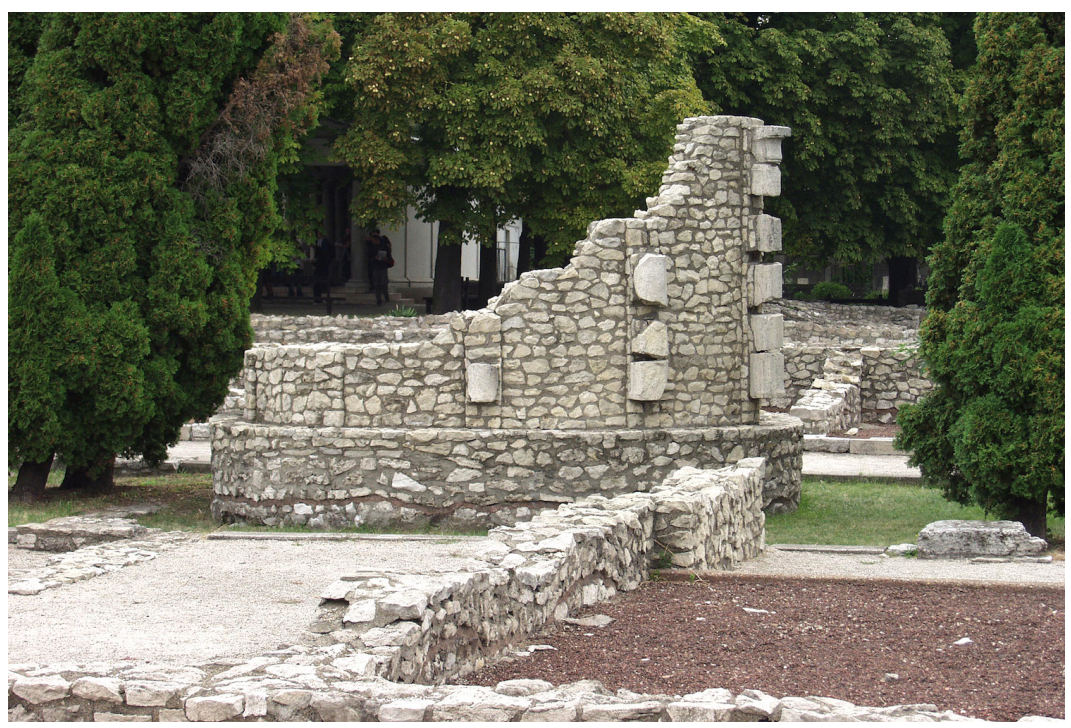

Figure 3. The rotunda of Macellum in Aquincum. (Photo: Tamás Mezős) 
the sidewall along a spiral and put the remains of the semi-columns found during the excavation onto it. Some tambour elements did not interlock with their area of fractures; thus fixing the semi-column trunks was only possible in phases. The construction carried out without permit almost prevented the works of the archaeological park to be continued. The authority referred to the Charter of Athens written in 1931 stating 6 that [the representatives of the participating states] "renounce the project of complete reconstruction". This volume of the "reconstruction" was unacceptable for the experts who were men of principles. It was only through lengthy reconciliations and negotiations that allowed both the archaeologists and the architects to maintain their positions.

The other endeavour to expand the limits of principles was bricking up the SE corner of the civil town Forum. Only at the price of extensive discussions and severe compromises was it possible to authorise placing the original cornice fragments - adjusted to the height of the columns found nearby - at the assumed original level of height. The comic element of the situation lies in the fact that in the absence of Hajnóczi, the building contractor finally placed the entablature of the wall one row of ashlar lower. The result was a logical contradiction between the height of the nearby re-erected column and the location of the cornice running, in theory, on this level of height.

Uncovering the building called the great public bathhouse was among the first significant results of the excavations of Aquincum initiated before the turn of the $19^{\text {th }}$ and $20^{\text {th }}$ centuries. The definitions of the functions of the individual rooms have changed since then. For example, the area marked by $\mathbf{C}$ was probably a palaestra rather than an apodyterium, changing room. The changing room was most likely the space covered by a roof marked by $\mathbf{F}$. Room $\mathbf{E}$ might have been the frigidarium (cold pool), the tepidarium (warm pool) could be $\mathbf{G}$, and $\mathbf{H}$ must have been the caldarium (hot pool). With all these taken into account, Hajnóczi tried to present each of the rooms by taking a didactic approach (Fig. 4).

In the given heated rooms, the structures of the underfloor heating and the suspensura could be preserved. Thus it was possible to reconstruct the original floor plane. The columns of the hypocaust were newly bricked up in many cases, and a reinforced concrete slab substituted the authentic flagstone and terrazzo cover. The presentation of the small pool of the caldarium was made of reconstituted stone. The sets of wall heating tubes could be preserved in their original place at two different locations. The lavatory, as part of the bath, has become a spectacular exhibition site. Since only a little of the vertical walls survived, both the operation of the underfloor heating and the alignment of the pipe system could be represented spectacularly.

It was in Gorsium, along the decumanus, near the Palatium where the remains of the so-called Basilica Maior lay; which, according to Jenö Fitz, archaeologist, is a Christian church built in the $4^{\text {th }}$ century. A building, considered to be constructed in

\footnotetext{
${ }^{6}$ The Charter of Athens. In: Book of Charters. $2^{\text {nd }}$ extended edition. Hungarian National Committee of ICOMOS (International Council on Monuments and Sites), Budapest 2011. 13. II.
} 


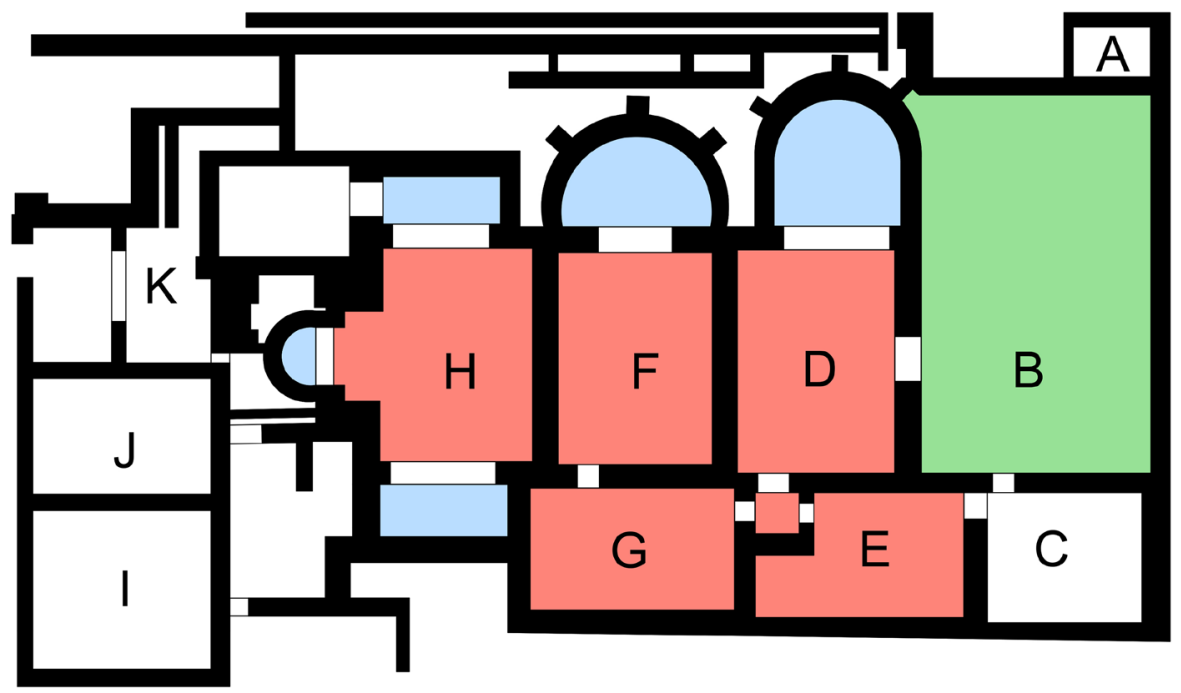

A: Fiscus; B: Palaestra; C: Latrina; D: Frigidarium; E: Vestibulum

F: Tepidarium; G: Vestibulum; $\mathrm{H}$ : Caldarium; I: Latrina

Figure 4. The floor plan of the Great Public Bathhouse in Aquincum. (Rec.: Tamás Mezős)

the $1^{\text {st }}$ century, was found under the basilica during the excavations; remains of valuable frescos were within. Hajnóczi, following the practice already adopted previously, ensured covering the space by partially bricking up the eastern wall of the

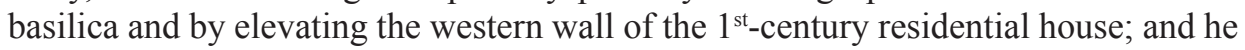
closed it with profiled glass walls. The architect presents the uncovered fresco elements, reconstructed with high standards, in the interior by placing them on panels (Fig. 5). The difficulty of presentation and interpretation represented the duality, which endeavoured to demonstrate the remains - originated in an earlier period, but subsequently demolished - within the walls of a building built later on.

\section{AN ATTEMPT TO RECONSTRUCT THE MASS OF THE BUILT HERITAGE}

In the early years, Hajnóczi's effort to create real architectural spaces was a protective building - erected above the mosaic depicting the wrestlers - of the so-called double-column hall and the room containing the mosaic of Dirke's atonement. In terms of the conceptual formulation of protective buildings, the international practice of the 60 s mostly preferred erecting a structure independent of the original walls. It was a new, fresh idea to construct abutments bricked up as columns, applying the load onto the original walls, which could support a monolithic reinforced concrete 

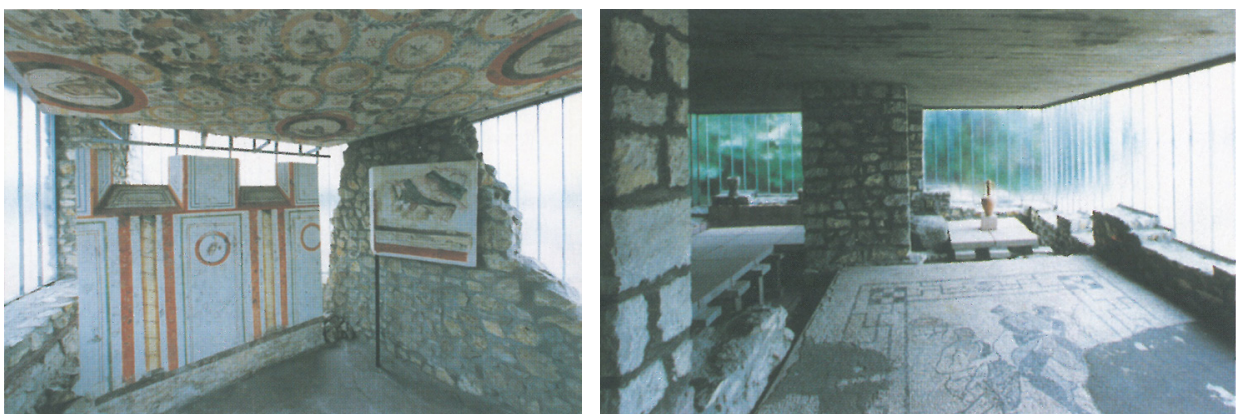

Figure 5. Reconstruction of the fresco building in Gorsium. (Photo: Gyula Hajnóczi)

Figure 6. The protective building of the Wrestlers mosaic in Aquincum, northern façade.

(Photo: Tamás Mezős)

floor (Fig. 6). The building of the mosaic depicting the wrestlers was initially divided into several rooms, which, in the protective building, only appear in the zone under the floor level. The "openings" between the columns bricked up on the exterior bordering walls were given by profiled glass wall that was a novelty application of industrial architecture back then. The ceiling height of the spaces might have been only the half compared to the spatial relations used in Roman times, or even less. The appearance of modern tools is perfectly recognisable when looking at the completed building.

Besides the Iseum, the other crucial work of Professor Hajnóczi was probably the protective building (Fig. 7) of the ruins of the main building (No I) of the agricultur-

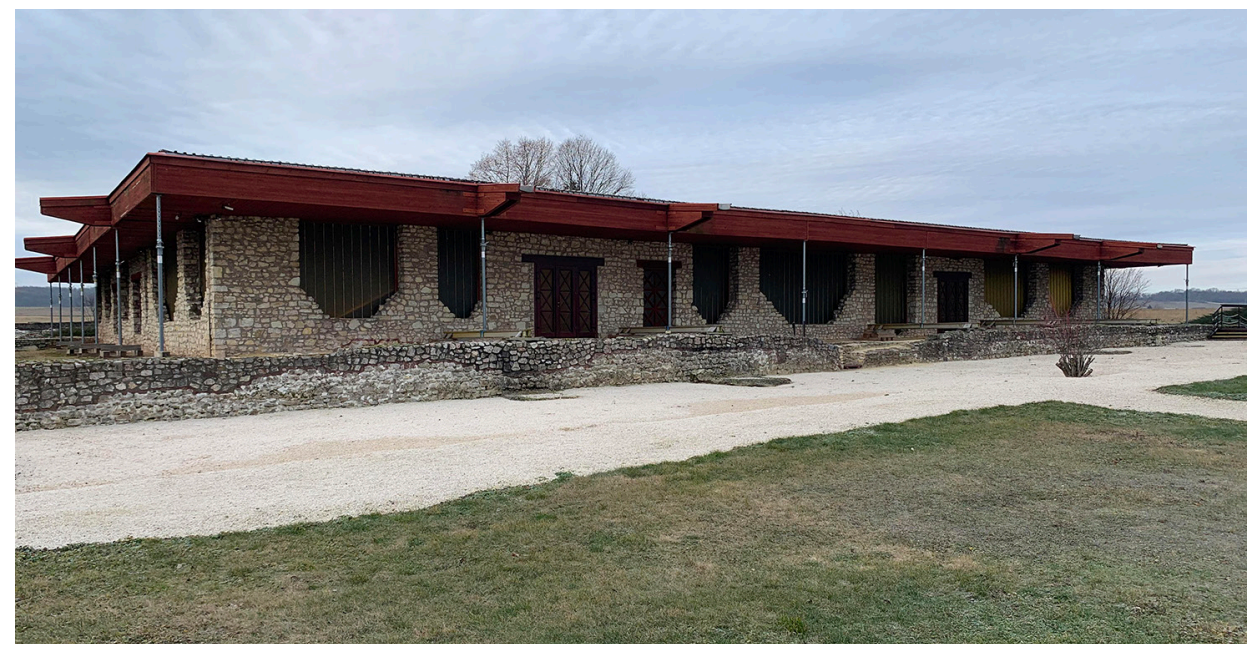

Figure 7. The view of the Roman villa in Balácapuszta. (Photo: Tamás Mezős) 
al villa estate in Balácapuszta between Nemesvámos and Veszprémfajsz, as well as the reconstruction of the nearby buildings numbered II., III. and X. The excavations led by Gyula Réh at the beginning of the $20^{\text {th }}$ century, then by Sylvia Palágyi starting from the 1970 s, uncovered valuable spaces covered by mosaic pavement among the ruins of the Perystile villa. One can admire the intact mosaic of the tablinum today in the lapidarium of the Hungarian National Museum. The masterly Roman work of art is presented on-site in the form of a replica. Almost 40 years after its opening to the public, the structure became dangerous for visitors to access. Although accepted plans were prepared to resolve the defects, the structure's renewal did not obtain the necessary financial resources besides essential and attracting investments. The new plans, which will probably be implemented sometime in the future, offer a conceptual solution alien from Hajnóczi's principal work's revival.

In terms of the theory of presentation, he took the method used on the protective building of the wrestlers' mosaic in Aquincum and applied it on a much larger facility. In the parapet strip, he "twanged" the abutments of the exterior bordering walls visualised as columns. It was impossible to reproduce the windows on the facade walls because archaeological data did not confirm their existence. The designer closed the interpilasters with profiled glass walls, the same way as he did in Aquincum. The low pitch roof's eaves of large projection served as protection for the walls. Hajnóczi originally planned a smaller projection. The roof had been designed steeper than the finally realised structure's; originally about $22^{\circ}$ in the plans compared to the present $5^{\circ}$ on average. The modifications - due to Hajnóczi's serious illness - were implemented without the consent or knowledge of the designer. This change in the execution became the reason for numerous structural defects that came up in the decades after the inauguration.

Spatial distribution was only executed at random in the interior. The replica of the mosaic pavement reconstruction renders the spatial relations of the floor plan palpable. The ceiling height of this building is, again, lower than it could have been once back in Roman times. According to the original plans, the pasted durable open truss would reveal an exciting spatial world in which the memories of the past could preserve their integrity and significance in the presentation. As a result of the previously mentioned structural modifications the timberwork got damaged, entering certain parts of the villa became unsafe. The different plans proposed to reconstruct the roof did not consider the original intention of the designer and suggested metalwork solutions alien to the building.

Most probably, the presentation of the mausoleum of Kövágószőlős is the closest to mass reconstruction in Professor Hajnóczi's oeuvre. Alíz Burger uncovered the mausoleum and the villa just north of it, in the area of the uranium mines of Pécs, in the proximity of the slurry storage. The presentation of the building only reached the phase of creating the didactic band. The protective, explanatory pieces of masonry were not carried out. Nonetheless, the exhibition, then the opening ceremony of the mausoleum, including the hypogeum and the cella memoriae, did take place. The painted walls of the burial chamber preserved the spring line of the barrel vault, and 

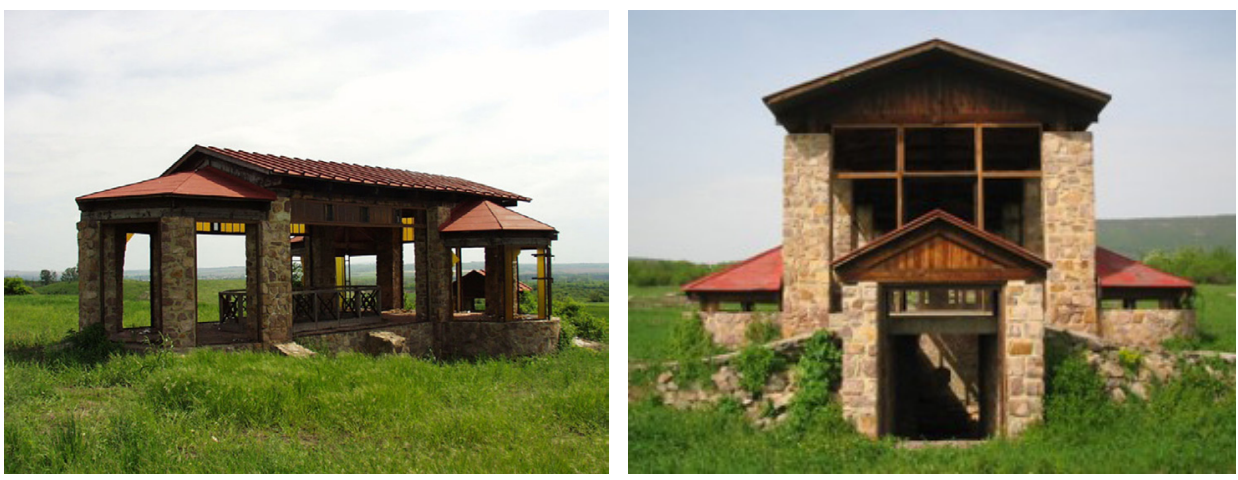

Figure 8 a-b. Mausoleum in Kővágószőlős. (Photo: Tamás Mezős)

the initiation of the arch was also visible sporadically. Thus, the complete reconstruction of the lower area could be implemented authentically, and the floor plane of cella memoriae was also elevated onto an acceptable height. Hajnóczi did not build a plain reinforced concrete slab onto the - adequately positioned and statically appropriate number of - columns of the vertical walls. He rather covered the building by the reconstructed low pitch Roman roof (Fig. 8). The interpilasters were closed by a yellow profiled glass wall. Archaeologists did not support the idea of visitors going into the painted burial chamber regularly. That is the reason why the "cut-out" having an octagon floor plan was established in the centre of cella memoriae, through which the Roman frescos became visible. According to the archaeologist's proposal, Gyula Hajnóczi resolved the entrance of the burial chamber by an entrance building. However, as research conducted in the sepulchral structures of the early Christian cemetery shows, likely, the hypogeum had not accepted visitors continuously. The remains of the wall-strings found on the two sides of the descent probably only served as a protection of the stairs. The entrance of the burial chamber, the crypt was open just on funeral occasions. Presumably, the anteroom of the mausoleum was concealed by fill, continuously.

For a while, the frescos decorating the burial chamber were put in stocks to prevent them from decay. This idea could work until the minefield was a restricted, guarded area. The building once reconstructed by busy work fell into decline after the closure of the uranium mine. The glass walls of cella memoriae were shattered, the entrance of the hypogeum was forced open, and the plank screenings protecting the frescoes were removed. The Roman frescos left unprotected for decades disappeared.

It was within the framework of the bridge reconstruction works of Budapest in the second part of the 80s that the widening of Árpád Bridge and the rearrangement of nearby Flórián Square were carried out. Large-scale heritage conservation and restoration works happened relating to the road bridge running from the direction of Szentendrei Street up towards Árpád Bridge since this is the area where Thermae Maiores, the great bathhouse of the Roman military camp was found in the $18^{\text {th }}$ cen- 
tury ${ }^{7}$. Hajnóczi would have liked to undertake planning the presentation of the military bath under the overpass, which was only in the planning phase at that time. Finally, László Ágostházi, a colleague of the Institute for Town and Regional Planning and Research, solved the task with a high level of quality. Perhaps to provide a little comfort, Piroska Csetényi, head of erstwhile existed Budapest Inspectorate for the Protection of Monuments, commissioned the Professor with planning the presentation of the eastern gate of the camp. Even the opportunity itself is an exciting story to start with, namely, to make visible the exploration of the building providing access to the praetorium in the direction of the Hajógyári Sziget, and to designate the construction site. It was possible to present the gate at the original floor level due to the wrong determination of the geodesic line of the foundation levels of the care home standing in the forefront of the onetime gate and the prefabricated buildings towering behind it. The exploration is credited to the name of Margit Németh, archaeologist.

\section{COMPLETED SMALLER-SCALE PLANNING TASKS}

Compared to the ones mentioned so far, it might seem an unimportant work to present the decorating fresco of a room located in one of the barrel vault halls of Tata Castle, excavated among the ruins of one of the buildings of the Roman Brigetio. According to the results of an opinion survey conducted among the visitors of Tata museum, the sight of the Roman room was a lasting experience for the majority, something that is worth coming back for in Tata Castle. The room is still one of the most visited scenic spots of the castle today. Endre Bíró, archaeologist, fit together the pieces of the view of the sidewalls of the room as a result of decades of fine work. Here, architectural work included designing the supporting structure of the plaster debris mounted on panels. The pictures kindred to the Italian decoration painting of the $2^{\text {nd }}$-century revival period were created in the third Pompei style. Placing the fragments onto boards, and then fixing them bear the imprint of the quality work of restorers Miklós Móré, Péter Márkus (vertical surfaces), and István Bóna (vault).

Another task of the second part of the 80s was to restore the civil town amphitheatre and to create the possibilities of utilisation. The monument separated from the civil town is bordered by the embankments of the light rail of Szentendre and the railway of Esztergom from east and south, respectively. The restoration was completed by one single master mason and two assistants through many years of hard work under on-site supervision. All three of them were compulsorily retired workers of the closed mine of Dorog. Thus, the result of the work carried out with great attention and expertise is rightly the merit of uncle Pista too (whose surname, unfortunately, I forgot). Since the $19^{\text {th }}$-century archaeologist sold the well-preserved rusticated ash-

\footnotetext{
${ }^{7}$ István Schoenwiesner, guardian of the National Museum, uncovered the remains, and by the permit given by Maria Theresa, he ordered the erection of a protective building above the ruins. Thus he realised the first conscious heritage conservation intervention in Hungary.
} 
lars to the farmers in Békásmegyer, Hajnóczi had to plan the external rusticated ashlar apron-wall that provided the cover of the core. As for the tableau, he chose the one presenting Forum Rostra in Rome. The ashlar sized stones were made of concrete, and quarry-stone fragments covered the end-surface. The parapet stones - since nobody bought them due to their large size - could be replaced to the crown of the northern ring almost without loss.

Fenékpuszta, located in the proximity of Keszthely and Balaton, has an incredibly high touristic potential. Numerous design competitions and plans - ordered by László Czoma, former director of the castle museum - were drafted for the reconstruction of the built heritage, as well as for reviving the Festetich manor located west from it. Unfortunately, the mansion has now become the shelter of homeless people, while the ruins have deteriorated into a weed-grown area of left behind mounds of periodical excavations.

When presenting the southern gate, the designer tried a method that had not been applied before in Hungary. According to the Roman model, he ordered to brick up the exterior and interior apron-wall higher and to spread soil and turf at the top of the wall core. The solution native in England and Germany may not be regarded as unsuccessful. Probably the moisture-retaining feature of the turf could help to prevent the wall sections from freezing-out.

The remains of the northern wall of the contra fort were discovered during the construction of the new Elisabeth Bridge. Little cases were placed into the southern retaining wall, including the replicas of the archaeological findings uncovered in the area. Although the ruin was situated in the city centre, at a place of high traffic, it soon became the dwelling of homeless people. The lowered space has become just the ideal place of a football pitch for the children. The most recent rearrangement of the ruins was to cover them up, according to the decision of the capital. Illumination of the space under the floor level was solved by applying a natural method, through a wretched box, which was considered by the authority as a possible means of a skateboarding jump ramp, so it has become cordoned off. Budapest History Museum did not undertake the maintenance of the presentation site, and the local government of Budapest also felt a lack of ownership concerning the remains. The ruins of Contra Aquincum have practically been lost for the public.

The area of the onetime bath, in the outskirts of Százhalombatta, in the neighbourhood of the mouth of the river Benta, had not yet been explored when the assignment was given. Yes, archaeology has not stepped up yet to do this. The protection roof raised above the only room of the floor plan rested on $2 \times 5$ reinforced concrete pillars. The crust and the cornice formation were made of corrugated sheets. Nowadays, the ruins are becoming more and more deteriorated, and the wall remains are frequently the target of vandalism and destruction. To ensure preserving the Roman wall texture, probably it would be essential to consider backfilling the walls standing outside of the embankment. Thus the small bath could be protected from the effects of regular floods in the flood plains. 


\section{THE AUSTRIAN ASSIGNMENT}

It was an honour of an invitation for Professor Hajnóczi when professor Werner Jobst asked him to survey and create the schematic reconstruction plan of the ruins of Carnuntum, the onetime capital of Pannonia Superior. We studied the ruins of the so-called Spaziergarten and the Palastruine in two phases. The analyses conducted on the spatial structure of the latter one also verified that the remains hid the ruins of a large public bathhouse rather than a palace. According to the schematic reconstruction of this building, we can present the coloured architectural renderings of the external and internal visual presentations (Fig. 9).

Naturally, a brief presentation is not sufficient to introduce every idea that was completed and also those that have remained in the planning stage. I would only touch upon the plans drafted for the presentation of the building complex in Fazekastelep excavated near the factory of Füzfö. When it became clear to Hajnóczi that the unexplored area of the civil town on the western side of Szentendrei Street may never become a presentable archaeological park, he planned the finely considered reconstruction of Victorinus Mithraeum found close to the building of the Aquincum Museum. He acquired the building permit, too. Similarly, the reconstruction of the tumulus at Likas-domb in Balácapuszta could neither be implemented as imagined by the Professor. The Roman exhibition planned below the OTP branch in the main square of Szombathely could have been an exciting space of presentation,
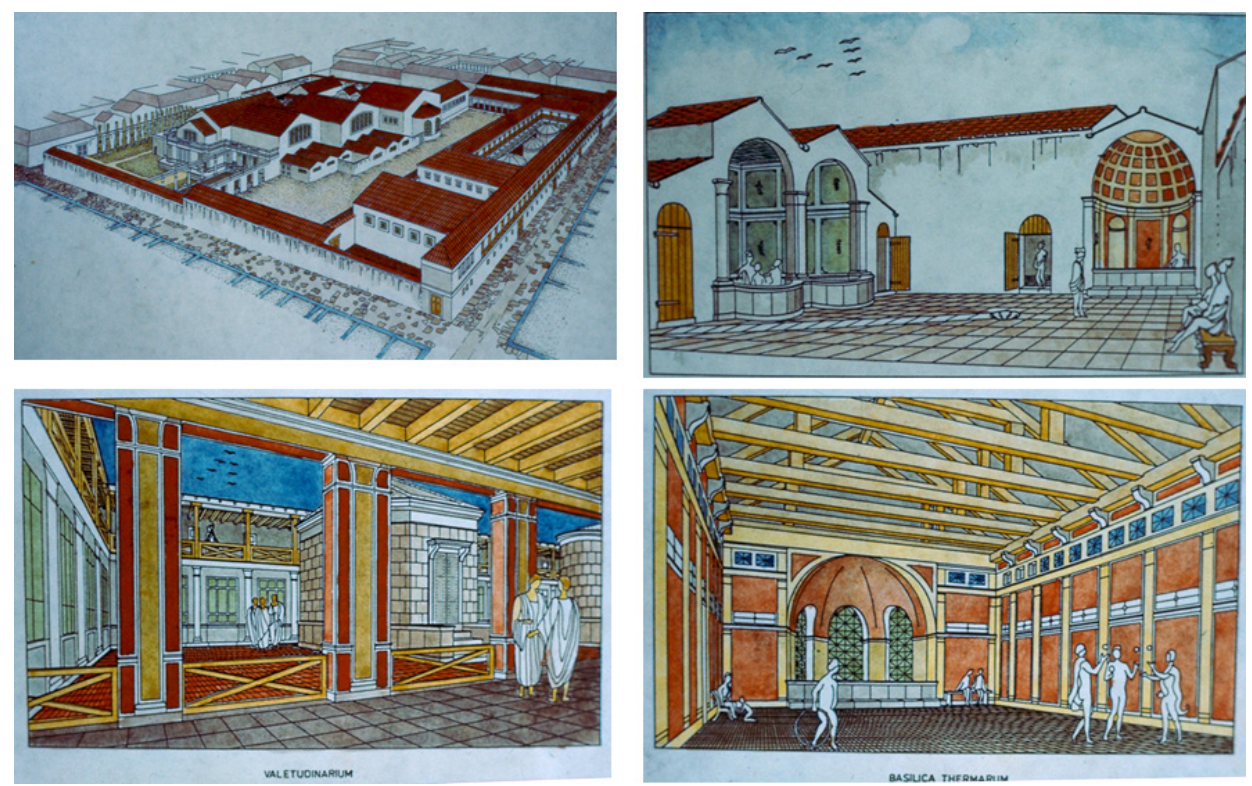

Figure 9. The so-called Palastruine, but practically the reconstruction drawings of the public bath in Carnuntum. (Gyula Hajnóczi) 
which would include the presentation of the meeting point of Borostyánkö Street and the aqueduct discharging from the west, as well as constructing an exhibition space. As a follower of Professor Hajnóczi, finally, I had the pleasure of creating the latter two heritages. Likas-domb has been revived in the form of a ruin presentation; unfortunately, the planned landscape architecture environment has not been established in the absence of plant treatment. The exhibition in Szombathely could finally be realised only on a fragment of the surface due to the austerity policy of the client, OTP Ingatlan Rt. The almost $20 \mathrm{~m}^{2}$ glass roof built in the hall of the bank branch establishes the connection between past and present.

The Hungarian Academy in Rome organised an exhibition about the Roman heritage of Budapest. Architect Katalin Kiss, head of the Department for the Protection of Settlement Heritage of the Mayor's Office was responsible for performing the exhibition. The plans included creating a maquette based on the schematic reconstruction of the remains of the praetorium at Hajógyári Sziget, which, naturally, was sent to Rome later on. The schematic reconstruction reflected Hajnóczi's assumption - based on the evaluation of the many times contradictory archaeological data - that the palace might have had two stories. The maquette was created according to these drawings, and then, decades after, the intention was also established to complete the reconstruction of the building following Professor Hajnóczi's idea. Counter arguments are being delivered against the two-story solution. Still, nobody has a series of archaeological surveys at hand that would be comparable with each other, which at this moment could provide accurate data. Despite the arguments, a verification excavation should instead be put forward, and an architectural periodisation - elaborated according to the analyses of spatial structure and historical documents - could be the basis of a schematic reconstruction determined with sufficient certainty, and then, of planning the presentation.

Professor Hajnóczi regularly published his research findings and documents related to completed restorations. His known work introducing the explored ruins in Pannonia is a volume entitled The Roman Ruins of Pannonia, which was published by Müszaki Könyvkiadó. ${ }^{8}$ I had the chance to accompany him during his site reconnaissance surveys where we could also meet archaeologists exploring the sites. It was a valuable experience for me to ear-witness the discussions of colleagues who had cherished decades of friendship. Our leaders were Sándor Soproni and László Barkóczi at the Danube Bend, Jenő Fitz in Gorsium, János Gömöri in Sopron, Róbert Müller in Fenékpuszta, Ferenc Redő in Zalavár, Sylvia Palágyi in Baláca, Endre Bíró in Tata, while Eszter Vágó, her husband István Bóna, and Barnabás Lőrinc were in Dunaújváros. Hajnóczi created a new schematic reconstruction drawing about each of the sites that were added in the volume. The book was sold relatively quickly; the publisher did not embark on issuing a new edition. That was the time when the idea was born to write a travel guide in four languages, entitled Pannonia Hungarica

\footnotetext{
${ }^{8}$ Hajnóczi, J. Gyula: Pannónia római romjai [Roman Ruins of Pannonia]. Müszaki Könyvkiadó, Budapest 1987.
} 
Antiqua $^{9}$. Later on, Hajnóczi wanted to expand the volume into a series, entitled Itinerarium Hungaricum. Hajnóczi wrote the first volume based on the data provided by the archaeologists of the given sites. He used the drawings he created for the work entitled The Roman Ruins of Pannonia, and he also took new photographs. Ildikó Proszlay - our wonderful colleague who passed away at an early age - was responsible for the second volume of the unfinished series that presented the heritage of the prehistoric era.

He put together his notes entitled Survey of Monuments ${ }^{10}$ based on the experiences he gained in the architectural survey of monuments at the beginning of his career. He wrote the chapter introducing Roman architecture for the request of his admired Professor, Jenö Rados. The study was published in the volume entitled Hungarian History of Architecture. In his publications, he studied the subject of Buda's bath architecture, and together with Klára Póczy, he developed the geometric construction system of the two amphitheatres of Budapest. His volumes and papers on architecture history and architecture theory enrich the literary canon of the science of architecture.

The oeuvre of Professor Gyula Hajnóczi was interconnected with the University of Technology. There was hardly any day when he would not come into the Department between 1946 - the year of his second enrolment - and 1996, the year he passed away. Since 1870, the year when the "founding fathers" initiated the education of the history of architecture, the forthcoming 125 years had hardly given any professor to the Department whose view and oeuvre would not have been led by the trinity of education-planning-research. Frigyes Schulek or István Möller could show tangible achievements when determining the construction periods of historic buildings. Károly Csányi issued papers on the history of medieval architecture. Before his death, Virgil Nagy published his work entitled The Morphology of Greek and Roman Architecture, which is still a useful piece today. Although Samu Pecz was mainly interested in medieval architecture and structure history, he wrote his habilitation thesis on the development of early Christian church architecture.

Gyula Hajnóczi was one of the last representatives of the post-war generation, who fully maintained the trinity stated in the teaching credo. Followers like us should continue promoting this example, the unity of education-research-planning in the first place, which testifies the life of Professor Hajnóczi.

\footnotetext{
${ }^{9}$ Hajnóczi, Gy.; Mezős, T.; Nagy, M.; Visy, Zs. (eds.): Itinerarium Hungaricum I. Pannonia Hungarica Antiqua. Archaolingua Foundation, Budapest 1995. (In Hungarian), 1998. (In German, English, and Italian languages).

${ }^{10}$ Hajnóczi, Gyula: Müemlékfelmérés [Survey of Monuments]. Tankönyvkiadó Vállalat, Budapest 1956. (Építöipari Müszaki Egyetem Tudományos Közleményei [Publications of the University of Architecture and Technology] Vol. 1. 6.
} 


\title{
HAJNÓCZI GYULA PROFESSZOR ÉLETMÜVE A PANNÓNIAI RÓMAI KORI ÉPÍTETT ÖRÖKSÉG BEMUTATÁSÁBAN
}

\author{
Összefoglaló
}

\begin{abstract}
Hajnóczi Gyula professzor munkásságát azonos súllyal jellemzi oktatói, kutatói és mủemlékes építész tervezői tevékenysége. Oktatóként közel fél évszázadon keresztül adta elő az ókori építészettörténetet és az egyetemes építészetelméletet. Kutatta és publikálta eredményeit építészetörténészként az építészetelmélet kutatójaként, a római kori építészet tudósaként és nem utolsó sorban az ókori világ építészete térelméletének megismerőjeként. Műemlékvédelmi munkássága nem csupán Magyarországon vált ismertté. Publikációi nyomán itáliai, német és osztrák kollégák keresték föl rendszeresen, hogy megismerhessék legújabb alkotásait. Nemzetközi konferenciák rendszeres előadójaként maga is sokat tett a hazai müemlékvédelem nemzetközi megismertetéséért és elismertetéséért. A dolgozat, a szük terjedelmi korlátok miatt, elméleti megközelítésben vázolja föl a romok konzerválásának módszereit, a védőépületeknek, mint redukált minőségü rekonstrukciós kísérleteknek a bemutatását, és nem utolsó sorban azt az elméleti megalapozottságú munkát, amely az épületek elvi rekonstrukciójának elkészítését kísérte.
\end{abstract}

Kulcsszavak: Hajnóczi Gyula, római régészeti leletek, örökségvédelem

Open Access statement. This is an open-access article distributed under the terms of the Creative Commons Attribution 4.0 International License (https://creativecommons.org/licenses/by/4.0/), which permits unrestricted use, distribution, and reproduction in any medium, provided the original author and source are credited, a link to the CC License is provided, and changes - if any - are indicated. (SID_1)

$\$$ Received: 9 December 2020. Accepted: 11 December 2020

First published online: 28 January 2021 